\author{
Justyna Siemionow \\ University of Gdańsk \\ pedjs@ug.edu.pl
}

\title{
New media in the education of children \\ with and without disabilities from the perspective of the knowledge and actions of their parents
}

\begin{abstract}
Summary
The aim of the text is to draw attention to the need to undertake planned and targeted preventive actions in the family environment as well as to domesticate effectively the so-called new technologies that are already present in our social reality, in the process of the education of pupils, with special attention paid to children with disability degree certificates. The article also presents the results of a study conducted on parents of children aged 7-12. The respondents were divided into two groups, parents of children with special educational needs due to various mental disorders, and parents of those with no such certificate. The two groups of interlocutors differed in terms of the extent to which they perceived Internet threats. A larger picture of this phenomenon emerges from the narrative of adults raising children with disability degree certificates, which points to the need to equalize opportunities and to keep pace with able peers, but creates many difficulties, including the already difficult process of educating children with developmental disorders.
\end{abstract}

Keywords: new technologies, disabled child, education process, virtual reality, risky behaviours

\section{Introduction}

This article addresses the topical and very important problem of the accessibility and use of new technologies in the educational processes of children and young people. The described study refers to children of school age. A study into children aged 7-12 was conducted, based on the assumption that the process of education is a deliberate and conscious complex of activities that shape the developing personality of the child, and that parents are the most important persons who control the process, and that their actions have a key impact on the psychosocial development of the child. The knowledge and the actions taken by parents regarding the use of new technologies by their children for various purposes was analyzed, while also highlighting the need to support contemporary parents in their educational efforts.

In this article new media and technologies are understood as all electronic innovations and technologies of information nature, and those connected with interpersonal communication, which create changes in the everyday life of society. They have changed the face 
of education, and expanded the areas of educational and socialization influences on children and young people by setting a new/different type of social relationships. New media provide people with easy, fast, and unrestricted access to information, and with the ability to co-create it, which meets the needs and requirements of the society of knowledge in which we live. School and family are the two main educational environments (Negroponte 1996). They are really associated with new technologies (virtual reality). In order for these environments to have a pro-developmental value, the parents, teachers, and educators creating them should take into account not only the potential for universal access to new technologies and media, but also the risks involved. The risks may, in particular, include the above mentioned unrestricted access correlated with insufficient attention devoted to children by their parents, the lack of close ties, and the cognitive and emotional capabilities of particular children contingent on their development (Andrzejewska 2014: 251-252). The changes in family life are implied by both external and macro-social factors and those inherent in family life - microsocial factors. The former factors are mainly the result of, among other things, reforms and implemented changes in the sphere of social policy and economy, and specific technical solutions or spatial development (Cudak 2015: 9-10). The automation and robotization of production and many services, computerization, the rapid development of computer science, the intensification of population spatial mobility resulting in a clash of cultures, the popularization of higher education, the intensification of already visible social atomization, are all processes that influence the shape and condition of modern families (Tyszka 2003: 82).

\section{Purpose and subject of the research}

The subject of the presented research is parental awareness and actions taken for the safe use (mainly as regards mental health) by their children of new technologies (e.g. phone, tablet, computer with Internet access). The research is embedded in the qualitative strategy, has a practical purpose and is intended to broaden and deepen knowledge about the activities of parents in the above-mentioned field.

Disability is an important factor in the risk of social exclusion. Involvement in the 'virtual world' and using new technologies are, in turn, factors which prevent exclusion, especially since today education in Poland is largely based on e-learning. The aim of this research is to draw attention to the problem of preparing parents and teachers to work with a disabled student with special educational needs.

\section{The persons researched}

The study group consisted of parents of children aged 7-12 who attend one of the primary schools in the area of the tri-city of Gdańsk-Sopot-Gdynia. The school offers teaching in both normal and the integration classes. The respondents are parents (mothers or fathers) of children assigned to either type of classes. The integration class is composed of chil- 
dren with a disability certificate (special needs). The Ministry of National Education (in Poland) defines pupils with special needs as those who, because of a disability, require special education and related services for their fullest potential.

The selection of the students was deliberate, dictated by cognitive considerations: the extension of knowledge about the object of the study on parents of children in the abovementioned age category, especially those with disabilities. The sample consisted of nine respondents, seven women and two men, aged 39 to 66 (five parents/guardians of children with disabilities and four parents/guardians of children with no diagnosed disabilities). The number of people researched was based on their availability and consent to participate in the research.

\section{Method}

Research activities were organized within a case study scheme, in the methodological literature called collective instrumental case studies, with cases chosen intentionally by the researcher in order to carry out an in-depth analysis of a phenomenon, problem, or process. With their help, multifacetedness and the widest possible picture of the phenomenon chosen for the study are presented. This is about the analysis of the problem related to the general, but through the prism of the concrete experiences of the researched persons (Kubinowski 2010: 172).

The conclusions of this study will be relevant only to respondents taking part in this study. The above elements were to be found in the presented research. Materials for the analysis were obtained thanks to a semi-structured, problem-focused interview (Rubacha 2008: 140). The interview enables the investigator to ask open questions and the interviewed person has freedom of expression when answering the question being asked. In addition, the previously prepared set of questions may change as to the order in which they are asked or the use of words and phrases that are appropriate and understandable to a given respondent. It is also possible for the interviewer to ask more detailed questions. All this serves to collect the necessary and possibly exhaustive data (ibid., p. 141). Using this method of collecting data made it possible to describe the experiences and activities of the researched people, as closely as possible to their perspective and to capture the context of their responses. When respondents were interviewed, they were asked questions based on previously prepared instructions. The research was of an individual nature, with no time constraints.

\section{Research questions}

In the presented research, answers were sought to the main research problem, which was: What do parents know about the use by their children of new technologies and what actions do they take to make the use safe and constructive? As a result, the following specific questions were distinguished: (1) Do parents know what effects (positive, negative) are 
entailed in their children's wide access to new technologies?, (2) What do parents know about the time, frequency, and types of the activities of their children as new technology users?, (3) Do parents of children with disability certificates have more information about the benefits and risks of using new technologies than parents of the children without disability?, (4) What ways and strategies do parents use to protect their children from irrational use of new technologies (including the Internet) and its consequences?, (5) What are the methods parents use to develop their children's creative attitude towards the use of new technologies?, and (6) From where do they derive knowledge and ideas about educational activities designed to increase the safe and creative use of new technologies by their children?

Between the meetings with the interviewees, the interviews already taken place were transcribed. Once the entire research material was collected, it was reduced by coding. It consisted of the careful reading of the subsequent sections of the respondents' responses and exploring the meanings contained in them. The next step was to give names to the codes so separated and to group them appropriately. In this way, the main threads (analytical categories) emerging from the obtained research material were outlined and ranked. According to G. Gibbs, coding may be applied to specific behaviours or activities of respondents, their activities, practices and strategies, but also their states, ways of adapting to the environment, or interactions (Gibbs 2015: 92-94).

\section{Presentation and discussion of results}

The respondents are parents/guardians of children attending one of the primary schools in the Pomeranian Voivodeship, which organizes education for children within the so-called norm $^{1}$ and for those with a disability certificate and specific indications for therapeutic work (integration classes). The children of the respondents belong to either the former or the latter group. What connects all the respondents is the fact that they perceive the farreaching benefits and risks of the use of new technologies by their children. Similarly, everyone is taking steps to ensure or improve the safety of their children when they use this equipment, and they also consult with others. During the analysis of the collected research material, two cases emerged when parents did not take any action so that their children could use their computer or tablet to develop their knowledge, talents or reduce visible and perceptible deficits. This type of behaviour was present in parents from both groups.

The two groups of interlocutors (parents of children with and without disability certificates) differed in terms of the extent to which they perceived Internet threats. A wider picture of this phenomenon emerged from the narratives of adults raising children with disability certificates. In the researched sample, only those parents associated the irrational

\footnotetext{
1 The term ,norm” is used by me as a kind of mental abbreviation, here - as a sign of a group of children in whom institutions and persons, such as psychological and pedagogical counsellors or disability evaluation boards have not diagnosed any disorders or significant deviations from the set of skills and level of knowledge determined as necessary for a given developmental period.
} 
use of new technologies with specific health effects. In addition, for the most part, the above-mentioned parents and guardians use new technologies to support and compensate for deficiencies in the development of their children (special programmes, work cards) but also as a tool for punishing and rewarding them. Moreover, the Internet as a source of knowledge and support (mainly emotional) for parental activities in this area was mentioned only in the statements of those respondents. In educational literature, a great deal of attention has been devoted to the possibilities of using and taking advantage of new technologies, both for learning and fun, e.g. programmes supporting learning to read and write, games that help to develop logical and creative thinking (Kulczycki et al. 2012; Stolińska 2008; Skreczko 2008; Siuda, Stunza 2012).

The positive aspects of a wide access for primary school children to new technologies, perceived by the respondents are mainly based on the two most important tasks in the developmental period, that is the taking of a new social role - the role of a student, and acquisition of specific skills, and an opportunity for intensive exploration of one's own talents or interests.

The researched parents/guardians perceive in the new technologies a potential for the development or shaping of children's skills which are helpful in fulfilling these developmental tasks. They perceive that using a computer or a tablet can improve their children's ability to acquire manual skills ("Undoubtedly, there are also games that produce dexterity and perceptiveness, I do not think I as a child had such opportunities"), as well as intellectual ("Well, definitely, some exercises to combat children's deficiencies, such as responsiveness, but here the games are appropriate, memorizing, focusing, memory exercises, they certainly give us technical possibilities").

In addition, the parents with children with disabilities indicated the possibility of compensating by means of new technologies for the various dysfunctions and deficiencies that their children have ("but new technologies that facilitate learning, for example, learning English, where this form of delivery is better for him, here I see the good side, yes"; "Ma'am, he watches fairy tales, he's got information about priests, as he writes church prayers for learning, he looks for that there, as he has these speech problems it's good for him.").

The respondents are also aware that such broad access to new technologies can have negative effects. The analysis of the interviewees in this category indicates that they perceive threats that may affect and often do affect four areas of child functioning: cognitive, behavioural, emotional, and somatic levels. Parental anxiety in the cognitive functioning of their children mainly involves contact of young people with content inappropriate for their age, which, if presented regularly and in an inappropriate form, proportion, or intensity may distort the child's knowledge of the surrounding world. Here is an example of a statement: "For example, content that shows things that are generally intended for adults, such as some drastic scenes, war scenes, for example, erotic or pornographic scenes, they should not be watched by a school-age child." The researches by Plichta and Kirwil which I would like to mention also concern the knowledge and actions of parents in the context of the discussed problem (Kirwil 2001; Plichta 2013). 
In the statements of the respondents, which may be both puzzling and interesting, institutions such as the school or psychological and pedagogical counselling centres which, in the framework of their responsibilities, offer various types of support, especially to families with children with disabilities, appear in the respondents' answers in the context of new technologies only in the case of two parents from both groups. Those are the persons who cannot (financial barriers) or do not need to (lack of specific deficiencies or disorders in the child) rely on the knowledge and experience of other consultants offering their services in private practice.

As part of the analysis of the respondents' responses to this issue, the main category was identified, which was called ,new actions" undertaken by parents on their own initiative. The mentioned term is close to the definition of innovation. Following Encyklopedia Pedagogiczna XXI wieku (The Teaching Encyclopaedia of the 21st century) the following definition of innovation has been adopted: introducing new ideas or practices in upbringing and teaching (Pilch 2004: 704). In addition, this type of activities is characterized by the creative inventiveness of their authors and the intention to obtain broadly understood progress or development as a result of their implementation. On the basis of parental practice, innovative (creative) activities may involve not only a change in, improvement of, or updating of the content transmitted to the children, but also the methods and means (tools) through which specific skills or knowledge are provided for them. Innovative solutions used by educators (including parents) can be implemented by transforming and adjusting the existing measures and methods of education to the present conditions and potential of children and young people, or by direct implantation of a particular idea or solution. In the former case, we talk about adaptive measures, while in the latter, about adopting concrete solutions to our own educational ground and use (ibid.: 703-705).

The use of various widely available programmes or solutions supporting the educational process in the case of the respondents has a purely technical and organizational dimension. They provide their children with proprietary programmes that support the learning of specific skills needed to continue learning in school, or to compensate for the deficiencies diagnosed in the child. The parents said: "He also has software for learning English, maths, because my son has a scientific mind, where he enjoys mathematics, we reach for a higher shelf for him so he can grow and do what he likes, we use software in the case of orthography because it is being now introduced". Another statement: "We have the 'Move the Mind' software, I get links and information, which is worth using. There are arcade games, stacking, colours, letters, numbers, so I say it's a didactic form that develops him manually."

The second type of innovation that emerges in the analysis of respondents' answers is based on the personal involvement (participation) of an adult in such innovative activities mainly by:

- modelling appropriate and useful (in the mind of the parents) skills in the child ("Just like yesterday, there was such a situation that we needed information about glasses, the book was not enough, so, our son "let's google" it, he just shows how 
he can use the web"; "we check together, well we write the entry "special school", and we check what textbooks there are, or we write the name of the book which the teacher buys for him, the kind of things that will come in useful for him"),

- providing knowledge about the possibilities of new technologies ("We talked, that is I and my daughter, about what you use it for when you need it and what one does with it, not just fun, to get information, so I generally tell her what it is used for, how it can be used for example in professional work").

The third, last type of innovation that is identified as "zero innovation" is understood as the declaration by interlocutors of a conscious failing to take any activity in the area described. This situation relates to two respondents. An additional category that emerged during the analysis of respondents' responses is the category called: instrumental use of technologies. This is a reference to the assumptions of pedagogical instrumentalism, according to which knowledge is considered from the point of view of the benefits it brings in practice (Okoń 2007: 137). In the case of the parents/guardians, knowledge is understood to be awareness of how important, exciting, and attractive new technologies are for their children. So the tablet or computer used in this way by the adults is a "gratifying" tool to help achieve a specific goal:

- the management of children's time, and for parents - getting help or relief in fulfilling their care obligations to their children ("there is a contract that, as I go out for an hour, because I have something to do and my son stays alone, I make an agreement with him that he can use the computer until I get back"),

- as an effective tool for punishing and rewarding ("It is known that if there was very good behaviour at school, he gets a maximum of three points at the end of the class from the teacher, he tells us when we pick him up at school, that today there is maximum points, well it's good; as a reward, you get extra play time on your computer").

When asked how much time their children spend on using new technologies at home the respondents indicated the use of a time span of between thirty minutes and an hour and a half. The respondents frequently said it was one hour per day, both in the case of children without a disability degree certificate and those with various deficiencies or disorders. Similarly, there is no significant difference in the responses of parents/guardians about the frequency of carrying out such activities by children. According to most of the respondents, their children have daily contact with new technologies, while three of them (two respondents with children with a disability certificate and one parent of a child with no certificate) believe that the youngest spend only from two to a maximum of four hours a week in front of a tablet or computer. It should be taken into account that the knowledge of all the parents taking part in my research into the time their children spend in front of a computer or tablet may be underestimated or incomplete, and the time of such children's activity is differently counted and qualified by the adults.

The analysis of the answers relating to this issue shows that this time is treated in a flexible way by the adults, and that it is shortened or extended depending on the age 
of the child, but also the purpose for which the youngest ones use the mentioned equipment. Here are examples of the statements: "Well, my eldest son has no limits, because he's smart enough to see what he's doing, it does not matter how much he uses it, he uses it wisely when the game turns off after an hour, in general he preferably looks for information"; "[...] it depends on whether we are working to prepare for the lesson and to do homework, because then there is more time, unless it is a form of relaxation and fun for him, then this time is severely limited by us"; "We type and look for this information, as I showed it to her now she looks for it herself, I mean I do not count that into the main time with the computer, because I call it help needed to do homework."

\section{Summary and conclusions}

The parents (including those with children with disabilities) covered by the research use new technologies as support in fulfilling their caring and educational tasks. The possibility of using a tablet or a computer as a kind of punishment/consequence or reward is particularly stressed by those with children with diagnosed disorders - children with disabilities. In their case, it is a constant and well-thought-out educational practice aimed (in the belief of these respondents) at obtaining or sustaining a particular reaction or behaviour of the child. It is very important that the parents are aware of the possibility of using new technologies in the educational process of their disabled child and they do very often use them. On the other hand, a student with a disability is equally or even more exposed to the risk of the negative consequences of 'virtual socialization' for his/her development than that of a student without a disability certificate. There is no doubt that technology has the potential to act as an equalizer by freeing many students from their disability in a way that allows to meet the needs of students with disabilities within regular classrooms, all teachers, both those in regular education and those in special education programs, need training in how technology can be used them to achieve their true potential (Hasselbring, Wiliams Glaser 2000: 119-120).

Digital media or new technologies are often used interchangeably in the literature of the subject, especially in the context of their undisputed influence on the education or upbringing of children and young people (Strasburger, Wilson, Jordan 2014). In the realities of current society, access to information, and more precisely the ability to select or administer it, is the key competence with which people enter into adult, mainly professional and social life. In this sense, new technologies can be an authentic environment eliminating all kinds of barriers, but also potential and new areas of social exclusion.

By summarizing the conducted research and the data collected from it, it can be stated that:

- the more diverse the respondents' concerns about the use of new technologies by their children, the wider the range of activities the respondents undertake to ensure their children's online safety,

- the number of positive aspects of children's access to the Internet is not reflected in the number of activities that prevent children from over-activity in the area, 
that is creative search for educational purposes and the introduction of alternative activities,

- the greater the range of consultations undertaken by the respondents (e.g. family, friends, web forums, etc.), the more likely the activities are to be nonhomogeneous and inconsistent, but also more likely to be taken by the parents both in the area of web security and in both types of "parental innovations" presented in this article.

Thus, it is important for all individuals who are involved in policy decisions regarding the placement of students with disabilities, teacher training, and the funding of educational technologies to become familiar with the issues surrounding the use of technology for students with disabilities. Working together, parents, teachers, administrators, and school board members, as well as both students with disabilities and their nondisabled peers, can help create classroom environments in which all students have opportunities to learn (Hasselbring, Wiliams Glaser 2000: 120).

\section{References}

Andrzejewska A. (2012), Nowe zagrożenia cyberprzestrzeni $i$ świata wirtualnego dla dzieci i młodzieży. W: B. Siemieniecki (red.), Edukacja medialna w świecie ponowoczesnym, Toruń. Wydawnictwo Naukowe Uniwersytetu Mikołaja Kopernika.

Cudak S. (2015), Model funkcjonowania współczesnej rodziny w Polsce. W: W. Muszyński (red.), Kondycja wspótczesnych rodzin. Toruń, Wydawnictwo Adam Marszałek.

Gibbs G. (2015), Analizowanie danych jakościowych. Warszawa, Wydawnictwo Naukowe PWN.

Hasselbring T.S., Williams Glaser C.H. (2000), Use of computer technology to help students with special needs. "The Future of Children, Children and Computer Technology", 10 (2). Available at: www.futureofthechildren.org (retrieved on 15/02/2018).

Kirwil L. (2011), Polskie dzieci w Internecie. Zagrożenia i bezpieczeństwo. Częściowy raport z badań EU Kids Online II przeprowadzonych wśród dzieci w wieku 9-16 lat i ich rodziców. Warszawa, SWPS-EU Kids Online-P1.

Kubinowski D. (2010), Jakościowe badania pedagogiczne. Filozofia, metodyka-ewaluacja. Lublin, Wydawnictwo UMCS.

Kulczycki E., Sieńko M., Siuda P. (2012), Wywiad skategoryzowany. W: Dzieci w Sieci-kompetencje komunikacyjne najmłodszych. Raport z badań. Gdańsk, Instytut Kultury Miejskiej.

Negroponte N. (1996), Being Digital. New York, Vintage Books.

Okoń W. (2007), Nowy słownik pedagogiczny. Warszawa, Wydawnictwo Akademickie Żak.

Pilch T. (red.), Encyklopedia pedagogiczna. Tom 3. Warszawa, Wydawnictwo Akademickie Żak.

Plichta P. (2013), Rodzice dzieci z niepetnosprawnościa intelektualna wobec korzystania z Internetu - próba zarysowania nowego obszaru badawczego i wstepne wyniki badań. W: P. Plichta, J. Pyżalski (red.), Wychowanie i kształcenie w erze cyfrowej. Łódź, Regionalne Centrum Polityki Społecznej w Łodzi.

Prezentacja wybranych wyników badań uzyskanych w ramach realizacji projekt „Postrzeganie zagadnień związanych z ochrona danych i prywatnościa przez dzieci i młodzież”. Available at: www.giodo.gov.pl/file/id_p/2733/j/en (retrieved on 04/04/2017). 
Pyżalski J., Rodzina i szkoła a przeciwdziałanie zaangażowaniu młodych ludzi w ryzykowne z zachowania online. Fundacja Dzieci Niczyje. Available at: www.fdn.pl/badania-fdn (retrieved on 09/04/2015)

Rubacha K. (2008), Metodologia badań nad edukacją. Warszawa, Wydawnictwa Akademickie i Profesjonalne.

Siuda P., Stunża G.D. (2012), Wprowadzenie. W: Dzieci w Sieci- kompetencje komunikacyjne najmłodszych. Raport z badań. Gdańsk, Instytut Kultury Miejskiej.

Skreczko A. (2008), Pedagogizacja rodziców w zakresie korzystania z mediów. W: J. Izdebska (red.), Media elektroniczne w życiu dziecka - wyzwaniem dla edukacji medialnej. Białystok, Wydawnictwo Trans Humana.

Stolińska A. (2008), Dziecko w społeczeństwie informacyjnym-zagrożenia i perspektywy w jego rozwoju. W: B. Muchacka, K. Kraszewski (red), Dziecko w świecie wspótczesnym. Kraków, Oficyna wydawnicza Impuls.

Strasburger V.C., Wilson B.J., Jordan A.B. (2014), Children, Adolescent and the Media. London, Sage Publication Inc.

Tyszka Z. (2003), Rodzina we wspótczesnym świecie. Poznań, Wydawnictwo Uniwersytetu Adama Mickiewicza. 